\title{
血小板検査法とその意義
}

\author{
福 武 勝 博** 北原武**
}

Key words : adhision, aggregation, release reaction, platelet factor 3 , platelet size

はじめに

血小板は流血中において，円盤状の形をして 循環しているが，種々の刺激により，血小板は 互に凝集を起したり, 変形したりする. 血管内 面にコラゲンなどの異物面が露出すると, 血小 板は最初に異物面に粘着し, 粘着血小板に流血 中の血小板が接触し凝集する. 正常の血管内 皮には血小板は粘着を起さないが，露出した Collagen 線維を含む内皮下結合組織には粘着 を起す1). その他あらゆる人工的表面に粘着を 起すととが知られている，しかし，異物面への 血小板の粘着は血小板の大きさ，血小板と血漿 との量的関係によっても変化するし，血漿蛋白 質は露出した結合組織に吸着され，血小板粘着 能を修飾する ${ }^{2}$.

血小板とコラゲンとの反応には Wilner ら3) によるとコラゲンの $\varepsilon-ア ミ ノ$ 基が必要であると 報告され，Jamieson ら シルトランスフェラーゼとコラゲンの不完全な 糖鎖との間に形成される酵素一基質複合体の形 成によると提唱した. $\delta$-ヒドロキシリジンの $\varepsilon$ アミノ基はコラゲンーグルコシルトランスフェ ラーゼ反応に必要であり, SH 阻害剂でこの反 応が阻止されると共に血小板のコラゲンへの粘 着が阻止されることが知られている5.

また，Puett ら ${ }^{6)}$ は血小板コラゲン反応で， 血小板膜上には少なくとも 2 つの結合部位があ り，その 1 つはコラゲンの三重らせん構造のポ リペプチド分子あるいはその特殊なアミノ酸配

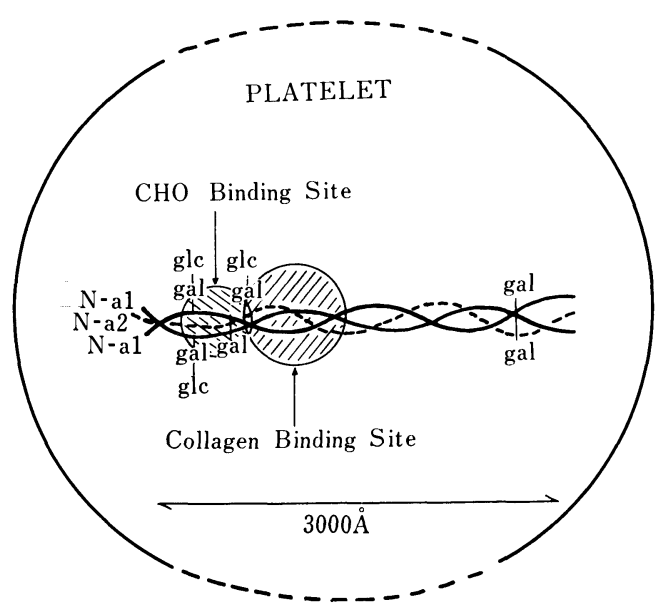

図 1 血小板とコラゲンの反応 (Puett, 1973)

列にきわめて高い特異性と親和性を持ち，血小 板凝集を惹起させる部位であり，他はこれとき わめて近接して存在し，たぶん血小板グルコシ ルトランスフェラーゼであると思われる糖結合 部位であると述べている.

血小板と反応するコラゲンの構造については Jeffe \& Deykin ${ }^{7)}$ が monomeric collagen, こ れの $23^{\circ} \mathrm{C}$ での重合物の microfibrillar collagen, monomerie collagen $の 37^{\circ} \mathrm{C}$ で重合した particulate native macrofibrillar collagen およびカ ルシウムの存在しない monomeric collagen の 塩析により作られた線維構成の不整な particulate collagen の血小板凝集能を比較し， microfibrillar collagen や macrofibrillar collagen 約60秒の潜伏期で血小板凝集を起とすのに対し

* Clinical significance of assay method for platelet function.

** 東京医科大学臨床病理学〔干160 東京都新宿区西新宿6-7-1〕, Katsuhiro FUKUTAKE, Takeshi KITAHARA :

Department of Clinical Pathology, Tokyo Medical College, Tokyo, Japan. 
表 1 血小板放出反応に対する阻止剂の影響

\begin{tabular}{l|c|c|c|r}
\hline \multirow{2}{*}{ Inhibitors } & $\begin{array}{c}\text { ADP } \\
\text { Release } \\
(\%)^{*}\end{array}$ & $\begin{array}{c}\beta-\text { Glucuronidase } \\
\text { Release } \\
(\mathrm{u} / \mathrm{dl})\end{array}$ & $\begin{array}{c}|c| \\
\text { Pvailability } \\
\Delta \mathrm{t}(\mathrm{sec} .)\end{array}$ & $\begin{array}{c}\text { Release } \\
\Delta \mathrm{t}(\mathrm{sec} .)\end{array}$ \\
\hline $\mathrm{ATP}$ & 37.5 & 27.5 & 8.4 & 7.4 \\
$\mathrm{AMP}$ & 60.7 & 20.0 & 7.0 & 6.4 \\
Adenosine & 8.2 & 10.0 & 0 & 5.2 \\
cAMP & 40.4 & 30.0 & 9.0 & 6.6 \\
PGE $_{1}$ & 13.6 & 0 & 0 & 5.4 \\
Ouabain & 45.0 & 25.0 & 0.2 & 3.0 \\
$\mathrm{NaCl}$ & $60.0 \pm 14.6$ & $24.6 \pm 7.0$ & $11.0 \pm 4.6$ & $8.6 \pm 2.2$ \\
\hline
\end{tabular}

* Maximum Aggregation Rate

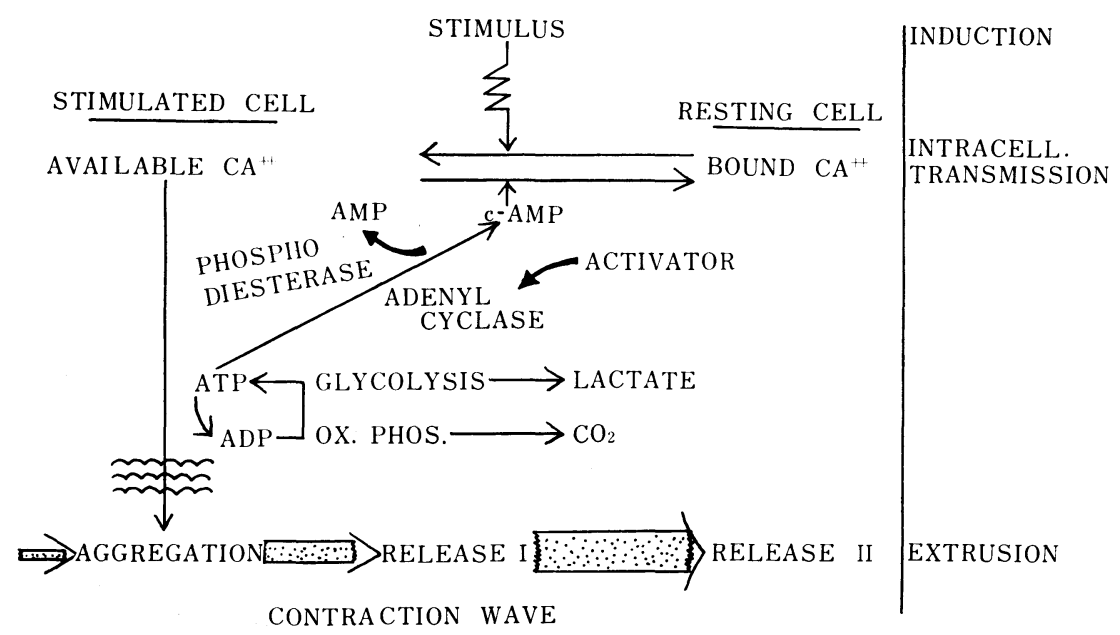

図２＼cjkstart血小板の代謝と放出反応（Holmsen 1971）

て, monomeric collagen は約 180 秒の潜伏期を 示し, particulate collagen は凝集能を示さな かった. また monomeric collagen は microfibrillar collagen に比べ, 粘着させる血小板数 が少く，それ自体の凝集効果は小さいととか ら，血小板を凝集させるには monomeric collagen が microfibrillar collagen に重合すると とが必要で, monomeric collagen での凝集で 潜伏期が長いのはそれを示すと報告している.

血小板がコラゲンなどに粘着すると, 粘着血 小板より種々の物質が放出される．乙の放出さ れる物質は血小板中の dense body と $\alpha$ 顆粒に 含まれる物質であることが知られている。 そし て，放出第 1 反応で放出された ADPにより， 血小板が不可逆的に凝集すると考えられてい
る. このような血小板の凝集反応に赤血球から の ADP が関係していると考えられており，血 小板の ADP と共に血小板粘着加ら血小板凝集 へと反応を展開すると考えられている.さら に，ADP ばかりでなく多くの物質が血小板放 出反応，血小板凝集を惹起しうることが知られ ている。

しかし, 最近の研究において, 試験管内での $\mathrm{ADP}$ に上る血小板放出反応は非生理的な低力 ルシウム濃度による人工的な反応であるとする 考え方がある ${ }^{8)}$.

\section{I. 血小板放出反応のメカニズム}

血小板放出反応の機序については Holmsen ${ }^{9)}$ は放出刺激により, 血小板膜のリン脂質, リポ 


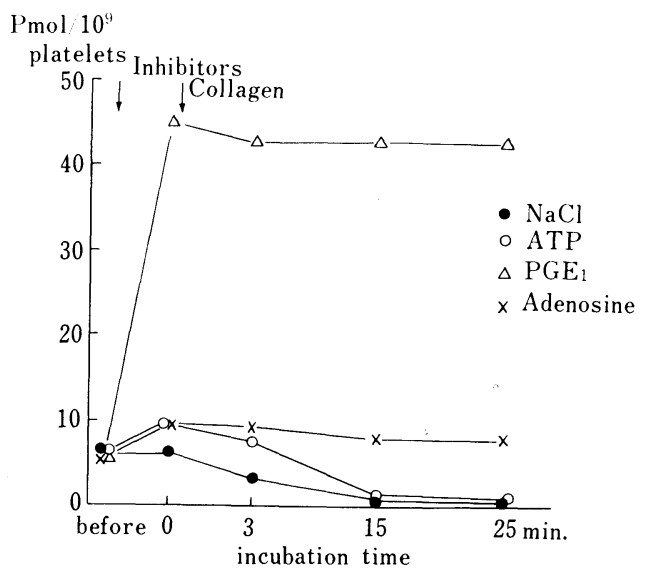

図 3 放出阻止剂添加による血小板 cyclic AMP の変化.

蛋白などに結合している bound Ca が遊離され

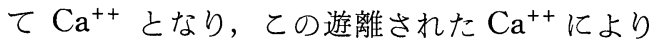
ATP ase が活性化され，ATP の分解が起ると 共に Thrombosthenine の収縮が起り，その結 果, 凝集, release I, release II と反応する. そして，遊離された $\mathrm{Ca}^{++}$が少量の場合には release IIは起らないし， $\mathrm{Ca}^{++}$が多量の場合に は release II まで反応が進むと述べている.

ATP の代謝経路として，ATP が adenyl cyclase により cyclic AMP となり, cyclic A MP が phosphodiesterase により 5-AMP とな る経路がある。 Salzman ら ${ }^{10}$ は $\mathrm{PGE}_{1}$ により adenyl cyclase を活性化すると血小板中のcyclic AMP が増加し, 血小板凝集が阻害されるとと を報告した。また， phosphodiesterase の阻害 剂であるパパベリン，テオフィリン，カフェイ ン, dipyridamole などは血小板中の cyclic A MP の蓄積を増加して血小板凝集を阻害するこ とが報告されている。われわれは $\mathrm{PGE}_{1}$ のみで なく adenosine も血小板中 cyclic AMP を增 加させ, release I, release II, 血小板第 3 因子 availability, 血小板第 3 因子 release を低下さ せることを報告した ${ }^{11)}$.

Booyse ら ${ }^{12)}$ は cyclic AMP の変動による血 小板凝集のメカニズムについて，血小板の膜に は cyclic AMP の受容体である cyclic AMP dependent protein kinase $と$ cyclic AMP dependent protein kinase receptor protein が存 在している. 血小板に刺激が加えられると， cyclic AMP の変動が起り, cyclic AMP が変 動すると cyclic AMP dependent protein kinase が活性化されて, ATP と cyclic AMP dependent protein kinase receptor protein との間に 無機リンの移動が行われ, cyclic AMP dependent protein kinase receptor protein $飞$ 結合し ている binding $\mathrm{Ca}$ が $\mathrm{Ca}^{++}$となり，細胞内に 流入して血小板凝集が起ると報告した.

血小板中の cyclic AMP の変動によって血小 板の反応が光進あるいは抑制されるとする説が 確立されつつあるが，コラゲンで血小板凝集が 起るとき血小板中 cyclic GMP が増加するとの 報告 ${ }^{13)}$ があり，また，phosphodiesterase には 3 種類あって, cyclic AMP に特異的な酵素々 cyclic GMP に特異的な酵素之両者を分解する 酵素があることが報告されている ${ }^{14)}$ ，そして， cyclic AMP は cyclic GMP phosphodiesterase の阻害作用を持ち，cyclic GMP は cyclic AMP phosphodiesterase の阻害作用を持つことが知 られており，てのように cyclic AMP と cyclic GMP を対比して考えた場合，血小板での cyclic GMP の役割も重要なむのであると思われる.

以上のように $\mathrm{PGE}_{1}$ が血小板に対して cyclic AMP を増加させ，血小板の反応を抑制する作 用を持つが，それに対して，トロンビンにより 血小板に $\mathrm{PGE}_{2}, \mathrm{PGF}_{2 \alpha}$ が産出され，放出され るととを Smith \& Willis ${ }^{15)}$ が報告して以来, アラキドン酸の血小板での代謝が血小板機能と の関連において検討されている．血小板膜のリ ン脂質が plospholipase により水解され，アラ キドン酸となり，とのアラキドン酸はサイクロ オキシゲナーゼにより, cyclic endoperoxide の 構造を有する labile aggregation stimulating substance $(\mathrm{LASS})^{17)}, \mathrm{PGG}_{2}{ }^{18)}, \mathrm{PGH}_{2}{ }^{18)}$ と呼 ばれる物質となり，乙の物質が血小板凝集や放 出反応を惹起することが明らかにされた ${ }^{16)}$. ア スピリンの血小板 への作用は cyclic endoperoxide の産生に関係するサイクロオキシ ゲナ 一ゼを失活させるためであると考えられてい る18). トロンビン, コラゲン，エピネフリン， $\mathrm{ADP}$ などによる血小板凝集において $\mathrm{PGG}_{2}$ や その他の代謝物の生成が認められており血小板 凝集はこれらの物質を介して惹起されるという 


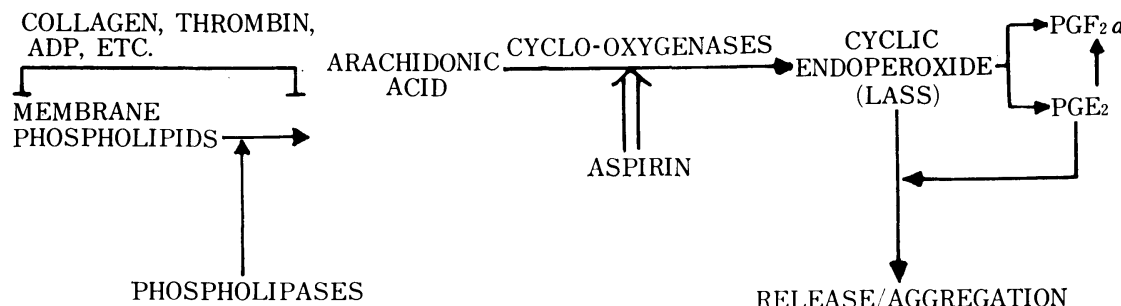

注1） $\mathrm{PGE}_{2}$ は直接に血小板凝集を起さないが,

LASS による放出反応，凝集を増強する. アスピリンにより LASS の生成は阻止される.

2）：せ阻止作用を示す.

図 4 血小板放出反応および凝集におけるプロスタグランヂン $\mathrm{E}_{2}$ の役割 (Weiss, 1975) ${ }^{16)}$.

考えが有力となってきた.また，血小板のサイ クロオキシゲナーゼ欠損によると考えられる出 血性素因の患者が報告されている ${ }^{199}$. 最近, 血 小板内で $\mathrm{PGG}_{2}$ より生ずる不安定な thromboxane $\mathrm{A}_{2}$ が $\mathrm{PGG}_{2}$ より強力な血小板凝集作用 を持つことが報告されている20).

\section{II. 血小板疑集のメカニズム}

次に血小板凝集のメカニズムについてなお不 明の点が多いが，ADP が血小板膜に結合し， $\mathrm{Ca}^{++}$を介して血小板が互いに結合するとの説, 血小板が unsticky の状態を保つために必要な ecto ATP ase が ADP によって抑制され, sticky となり，凝集を起すとする説などがあっ た. Booyse ら ${ }^{21)}$ は ADP が membrane ATP ase を抑制するため, membrane ATP が増加 $し$, membrane-bound actomyosin が ATP の 利用低下により, actin と myosin に解離し, actin と myosin が他の血小板の actin と myo$\sin$ に結合して，血小板相互にアクトミオシン 橋ができて凝集するという説を報告した。ま た，トロンビンは収縮蛋白の ATP ase 担体で ある myosin を解離し ${ }^{22)}$, epinephrine は thrombosthenin と結合して収縮蛋白を弛緩させ て凝集を起すと考えられている ${ }^{23)}$. Nachman ら 24 は血小板膜には ADP の receptor protein (actin F) が存在し, actin F の thrombosthenin ATP ase が ADP により抑制され, Booyse らの説と同様に actomyosin が actin と myosin に解離し, 血小板凝集が起 るとの説を発表し た.その他，フィブリノゲン，第XII因子，第 V
因子，第VIII因子，ガンマグロブリンなどあ血小 板凝集に関係があると考えられており，フィブ リノゲンの neuraminidase 処理によって血小板 凝集促進作用が失われること, von Willebrand 因子の欠損により ristocetin 凝集が低下するこ となどが知られている.

以上血小板の機能について概説したが，乙れ らの機能を検索するための血小板機能検査が多 数考案されている. 血小板検查の検查方法につ いては「血液と脈管」の血液検查法シリーズ （血小板検査法）にゆずり，本文では血小板検 查法のなかからいくつかの検査について，その 臨床的意義に解説を加えるととにしたい。

\section{【III. 血小板機能検査の臨床的意義}

\section{a. 血小板粘着能}

血小板粘着能の低下ないし欠如は出血傾向の 原因となるが，一方その妄進は血栓の形成に重 要な意義をあつあのと考えられる．したがっ て, 出血傾向を有する患者, とくに血小板数が 正常であって出血時間が延長するような場合に は, 血小板粘着能の低下は血小板機能異常症を 知る有力な手段となるととが多いし，また，血 小板粘着能の増加は血栓形成が䯚念されるよう な疾患においては，血小板機能立進を推定する 上で, 重要な検査法であると考えられる.

\section{1）血小板粘着能の低下する疾患}

先天性血小板機能異常症の多くは血小板粘着 能の低下が認められるが，乙れらは表 2 に示し た.グリコゲン蓄積症 ${ }^{25)}$, 先天性心疾患 ${ }^{26)}$ の先天性疾患に低下が認められ和との報告むあ 


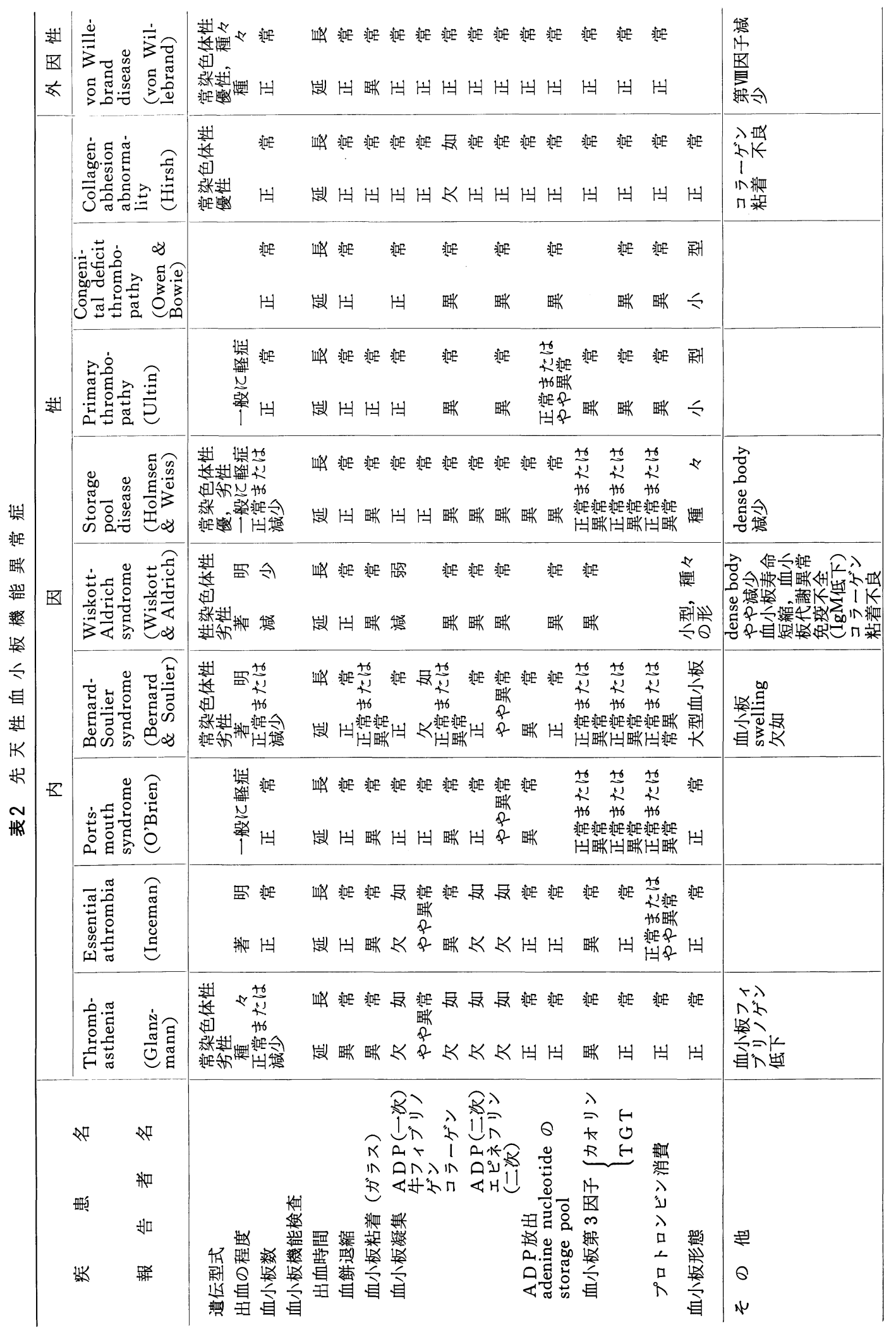


表 3 凝集率算出法と正常值

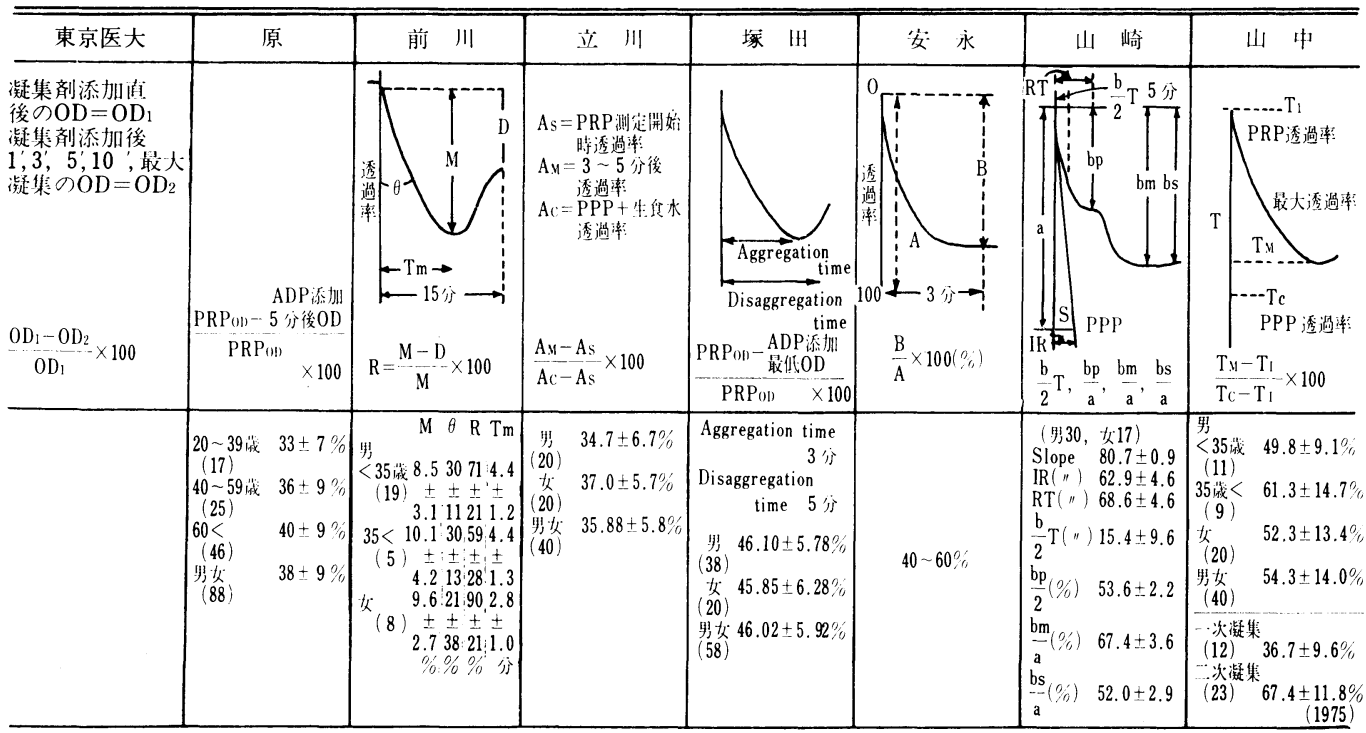

る。

後天性の疾患においては血小板血症 ${ }^{27) て ゙ は し ~}$ ばしば血小板粘着の低下がみられる，尿毒症 ${ }^{28)}$ では血小板粘着能の低下を認めたとする報告 と，低下を認めないとする報告 ${ }^{29}$ がある。その 他, 肝硬変 ${ }^{30)}$, dextran 輸注後 ${ }^{31)}$, ITP ${ }^{32}$, polycythemia vera ${ }^{33)}$, 急性白血病 ${ }^{34)}$, アスピリ ン投与後 ${ }^{35)}$ 亿血小板粘着能の低下が認められて いる.

2）血小板粘着能の六進する疾患

糖尿病では血小板粘着能が方進することが知 られている ${ }^{36)}$. また, 合併症として虚血性心疾 患をともなうものでは元進が著明である ${ }^{36)}$. 動 脈硬化症では血小板粘着能は元進するあのと低 下するむのが認められる ${ }^{37)}$. 虚血性心疾患にお いては六進が認められるとする報告 ${ }^{38)}$ と低下が 認められるとする報告 ${ }^{39}$ がある. その他, 高脂 血症, 手術後, 妊娠, 癌などで血小板粘着能の 六進が認められるととがあることが報告されて いる.

\section{b. 血小板凝集能}

血小板は異物面に粘着すると，引き続き血小 板が相互に付着して凝集し，凝集塊を形成す る. 血小板の粘着と凝集はきわめて類似した反 応であって, 多くの場合, 両者は平行して低下 あるいは六進を示すが，解離を示すととああ る. 血小板凝集能の測定法には顕微鏡下で血小

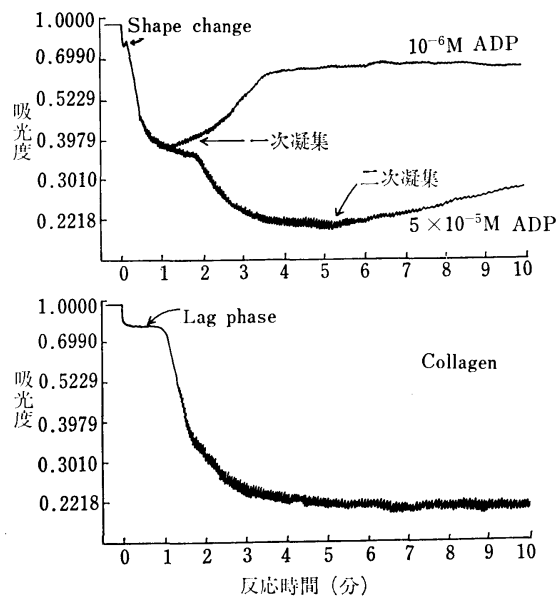

図5 ADP および Collagen による 血小板凝集.

板凝集塊の形成を観察する方法と血小板凝集塊 の形成により，多血小板血漿の濁度が凝集前の 多血小板血漿 (PRP) に比べ低下するととを利 用し, 光電光度計によりその変化をとらえる方 法とがあるが，日常の血小板機能検査としての 測定法としては後者が適している.

血小板凝集計を用いて各種血小板凝集誘発物 質を添加し，血小板凝集による吸光度の変化を 観察すると，図 5 に示した如くの曲線が示され る. 低濃度の凝集誘発物質を用いた場合, 誘発 
物質添加直後に血小板の円盤状から球形などに 変形することによると考えられる吸光度の一過 性の増加 (shape change) が起り, その後一次 凝集のみが誘発される。しかし, epinephrine を誘発物質とした場合には shape change が認 められない。高濃度の凝集誘発物質を用いた場 合， shape change，一次凝集に続き，血小板よ り放出された ADPによる二次凝集が誘発され る. 血小板機能の異常が軽度の場合には低濃度 の誘発物質を用いた時に障害を示し, 血小板機 能異常が高度の場合には高濃度の誘発物質を用 いてあ凝集を起し得ない。したがって血小板凝 集能の測定には 2 種類以上の濃度の凝集誘発物 質を用いるのがよい.

一般に血小板凝集能は血小板凝集率を用いて 表わされる. 表 3 にわが国で報告されている血 小板凝集率の算出法を示したが，研究者により 表現法も測定值むやや異なっている. そのた め，表現法を統一することが問題とされてい る.

1）血小板凝集能の低下する疾患

先天性血小板機能異常症では表 2 亿示した如 く低下するが，凝集誘発物質の種類によりその 程度は異なる。 その他血小板血症 ${ }^{27)}$, polycythemia vera ${ }^{33)}$, 急性白血病 ${ }^{34)}$, 肝硬変 ${ }^{40)}$ で血 小板凝集能の低下が認められる，また，尿毒症 であ低下が認められるが，人工透析により urea $\mathrm{N}$ ，クレアチニンの改善とともに正常化される といわれている(1). また，アスピリンの投与に より ADP 誘発による二次凝集の低下が認めら れる ${ }^{42)}$. その他, 慢性白血病, 悪性リンパ腫, ヴィールス感染症, 骨骾硬化症, 甲状腺機能立 進症，悪性貧血などであ凝集の低下があるとの 報告がある。

2）血小板凝集能の元進する疾患

動脈硬化症 ${ }^{43)}$, 糖尿病 ${ }^{44)}$, 心筋梗塞 ${ }^{45)}$, 血栓 症 ${ }^{46)}$ などで血小板凝集能の六進が認められると 報告されている. その他, 手術後, 高血圧, 妊 娠などによっても凝集能の充進が認められると する報告がある。

\section{c. 血小板放出反応}

Holmsen 弓 ${ }^{47)}$ は 血小板放出反応により放出 される物質は血小板内の dense body と $\alpha$ 顆粒

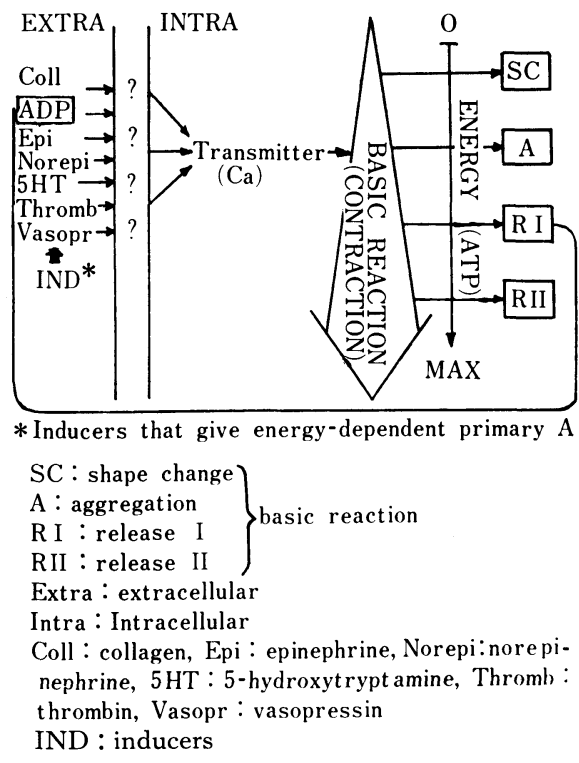

図 6 血小板放出反応のメカニズム (Holmsen, 1973) ${ }^{9}$.

に存在する物質に限局されており，それぞれの 放出反応を release I と release II に分類して いる. release I により, dense bodyに含まれ る ATP, ADP, セロトニン, カルシウム, 血 小板第 4 因子などが放出され，release II によ り， $\alpha$ 顆粒に含まれる酸ホスファターゼ， $\beta$-グ ルクロニダーゼなどのライソゾーム酵素が放出 されると報告している，また，Holmsen ${ }^{9)}$ は血 小板凝集と release I と release II との関係を 図 6 に示したように，血小板に刺激が加わった とき，血小板内のエネルギーが高まるにしたが って shape change, 凝集, release I, release II 引引き続く反応であると述べている，一般に 血小板の二次凝集は主として血小板の一次凝集 につづいて血小板から放出される ADPによる と考えられている。しかし，Weiss ら ${ }^{16)}$ は血小 板膜のリン脂質が誘発物質の刺激により活性化 された phospholipase によりアラキドン酸と なり，とれが cyclo-oxigenase により， cyclic endoperoxide となり,との cyclic endoperoxide (LASS) が血小板凝集，release I を起さしめ る物質であるとして図 4 亿示したような報告を している. 


$$
9: 8
$$

血 液之脈管第 9 巻第 1 号

いずれにしても，血小板の一次凝集，release I, 二次凝集之続く反応は密接な関係を持って いると考元られ，臨床的にも多くの場合，血小 板凝集能と release I は平衡するすのと思われ るが, Caen ら ${ }^{48)}$ は Glanzman 型血小板無力症 において各種誘発剂による血小板凝集は欠如し ているが，血小板よりの ADP の放出は認めら れると報告している。また，われわれの経験に おいても, Glanzman 型血小板無力症, essential athrombia において，血小板凝集は欠如し ているにもかかわらず，ADP 放出を認める所 見を得ており，血小板凝集能と release I の間 に解離がみられることがある。乙れは各種誘発 剂による血小板表面の粘着性の亢進が得られな いためと考えられる. このため，血小板機能検 査において，血小板凝集能の異常が認められた 場合，血小板放出反応の異常の有無を検索する 必要がある。

次に release II については血小板の $\alpha$ 顆粒が ライソゾームであり， release II により放出され る酵素には acid phosphatase, $\beta-\mathrm{N}$-acetylglucosaminidase, $\beta$-glucuronidase, $\beta$-galactosidase など種々のものがある．しかし，乙れらの酵素 の放出のメカニズム，作用機序についてはほと んご解明されていない. Kowalski ら ${ }^{49}$ は $\alpha$ 顆 粒中のリン脂質蛋白結合物が誘発刺激を受けて 活性化されたライソゾーム酵素により生成さ れ，ミセル化を起し membrane lipid complex となり，血小板膜下に移動し血小板第 3 因子と しての活性を示すと報告している。また，われ

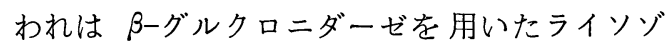
一ム酵素の放出之血小板第 3 因子 availability が同じ誘発物質により，ほとんど同時に誘発さ れ，同じ誘発阻止物質により阻害されることを 報告した ${ }^{50)}$ 。

\section{d. 血小板第 3 因子能}

血小板第 3 因子能は血小板の活性表面として の血小板第 3 因子能 platelet factor 3 availability と血漿中へ放出された血小板第 3 因子能 platelet factor 3 release とに分類されている. しかし，臨床的見地からはこれらが明確に区別 はされていない，血小板凝集の障害を主因とす る thrombastenia に対して血小板第 3 因子活
性の低下する疾患を thrombocytopathy（thrombopathy）ということが多い。また，さらに 血小板第 3 因子減少による deficit thrombocytopathy と血小板第 3 因子活性障害による functional thrombocytopathy とに分けられる ことあある．また，血小板第 3 因子能の低下す る疾患には先天性のものと後天性のものとがあ る。

先天的に血小板第 3 因子能が低下する血小板 機能異常については表 2 に示した.しかし，乙 れらの疾患のうちには同一疾患として報告され ているあののうちでも, 正常値を示すむのと異 常を示す症例とが報告されており,議論が多い.

後天的に血小板第 3 因子能が低下する疾患之 しては，Bowie ら ${ }^{51)}$ deficit thrombocytopathy に属するすのとして, 肝疾患, 腎不全, 壊血病，急性白血病などがあり，functional thrombocytopathy に属するものとしてマクロ グロリン血症, systemic lupus erythematosus, dextran 輸注などがあると報告している.

血小板第 3 因子能の低下は出血傾向をきたす が，血小板第 3 因子活性の元進は血管内凝血を 生じさせるとも考えられる(Kanfer \& Josso ${ }^{52)}$ ). また，脂肪酸，リン脂質は試 験管内で，血小 板凝集を惹起しうることが知られており，体内 局所での血小板よりの血小板リン脂質の放出は 局所での血小板凝集を促進するし，血小板粘 着，血小板凝集を経て止血血栓の形成を促進す ると共に，血管壁の病変によって血小板の粘 着，凝集を発症機序と考えられる血栓症の発症 における基本的な役割をなしているものと思わ れる。

\section{e. 血小板容積}

血小板機能の検査法として, 血小板凝集能, 血小板粘着能，血小板第 3 因子能の測定法が普 及してきたため, 血小板機能異常症の検索が急 速に進歩している. そして，血小板機能の障害 の程度と障害されている部位がしだいに明らか にされつつある. しかし，血小板形態の観察， とくに血小板容積に関しては血小板が粘着性, 凝集性を持つため，形態変化を起しやすく，ま 測定法もまちまちで，報告者によってかなり異 た，血小板の成熟度によって容積が異なるし， 

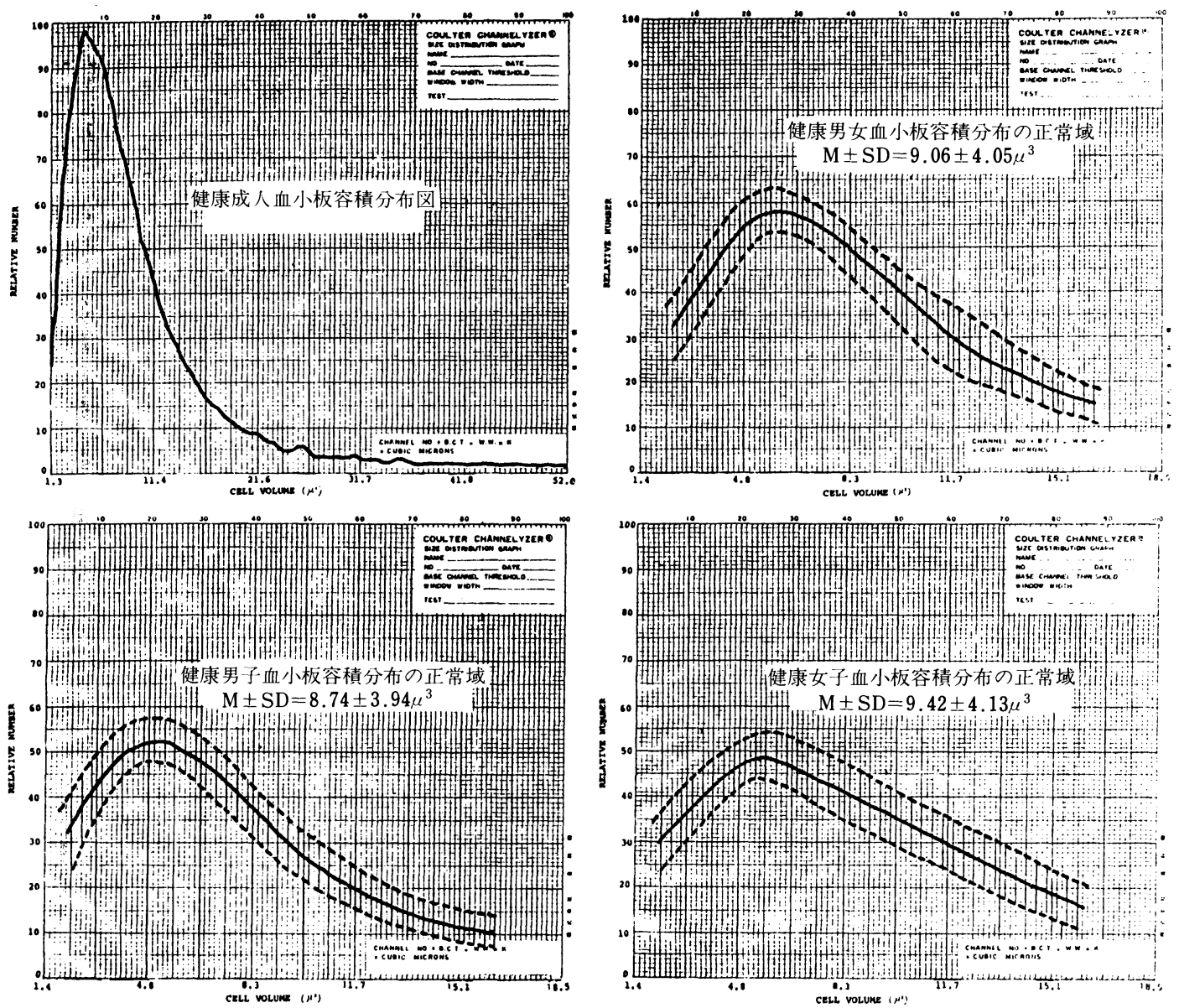

図 7

なった成績を報告している.最近, コールター・ カウンター・モデル ZBI 型とチャナライザー C-1000型を用い，迅速に，また，血小板を非固 定のまま，容積を観察することができるように なり，血小板容積測定の臨床的な意義が高くな ったと思われる．測定の原理は電解質液中に散 在している粒子を一定の電流が流れている細孔 を通過させるとき，細孔を粒子が通過するとと によって，粒子の体積分だけ電解質液が置換さ れ，電気抵抗が増加し，粒子の体積に比例した 電圧パルスが生じる.したがってての電圧パル スの大きさと数を電気的に測定するととによ り, 粒子数之個々の粒子の体積が粒度分布図之 して測定できるあのである。

乙れを用いた健康成人の血小板容積分布図を 図 7 に示した. 先天性血小板機能異常症では血
小板容積は正常域にあるものが多いとされてい るが, thrombastenia, essential athrombia では 大型血小板の増加傾向が認められ ${ }^{53)}$ ，われわれ は最近，極めて大型（約12 13 $\mu$ ）の血小板の 出現した essential athrombia の症例を 1 例経 験した. Bernard-Soulier symdrom では $60 \mu^{3}$ 程 度の極めて大きな病的血小板の出現が特徴であ

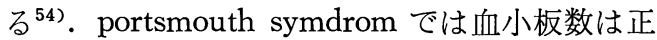
常で，そのピークは小型の方に移動し ${ }^{53)}$, Wiskott-Aldrich symdrom でも血小板数は減少し, 血小板の小型化もみられる ${ }^{55)}$. aplasia，DIC, ITP の血小板数は減少するが，大型血小板の増 加之共に小型血小板あるいは血小板断片の増加 が認められる ${ }^{53)}$ 。慢性骨䯣性白血病の血小板は ほぼ正常と類似した容積分布図を示し，急性骨 髄性白血病，糖尿病，悪性細網症，特発性夜間 
血色素症症などでは血小板容積の粒度分布は鋭 いピークとなり，かつ血小板の小型化が注目さ れる ${ }^{53)}$. また, 血友病患者の血小板容積分布図 はほぼ正常域にある患者と小型血小板が増加し ている患者とがあり, 血友病の出血頻度との関 係において，血小板容積が注目される。

一般的な血小板容積の病態の基礎として，(1) DICなどにみられる血小板消費は正常容積を屯 つ血小板すなわち最も活性の強い血小板から起 るので，小型血小板は残存しやすいとと，(2)血 小板生成が回復した時期には大型の幼若血小板 が出現するととなどに注目すると, 血小板異常 の関与する疾患の病態とくにその経過の解析に 血小板容積の測定は重要な情報を提供してくれ る.

\section{文献}

1) Spaet, T.H. and Stemerman, N.S. : Platelet adhesion. Ann. New York Acad. Sci., 201 (suppl); 13, 1972.

2) Evans, G. and Mustard, J.F.: Platlet surface reaction and thrombosis. Surgery, $64 ; 273,1968$.

3) Wilner, G.D., Nossel, H.L. and LeRoy, E. C.: Aggregation of platelets by collagen. J. Clin. Invest., 47 ; 2616, 1968.

4) Barber, A. J. and Jamieson, G. A.: Platelet collagen adhesion; characterization of collagen glucosyltransferase of plasma membranes of human blood platelets. Biochim. Biophys. Acta, 252; 533, 1971.

5) Spiro, R. G. and Spiro, M. J.: Studies on the biosynthesis of the hydroxylysinelinked disaccharide unit of basement membranes and collagens. 3. Tissue and subcellular distribution of glycosyltransferase and the effect of various conditions on the enzyme levels. J. Biol. Chem., 246 ; 4899, 1971.

6) Puett, D., Wasserman, B. K., Ford, J. D. and Cunningham, L.W.: Collagen-mediated platelet aggregation. Effects of collagen modification involving the protein and carbohydrate moieties. J. Clin. Invest., 52;
2495, 1973.

7) Jaffe, R. and Deykin, D.: Evidence for a structural requirement for the aggregation of platelets by collagen. J. Clin. Invest., $53 ; 875,1974$.

8) Mustard, J.F., Perry, D.W. Kinlough-Rathbone, R.L. and Packham, M.A.: Factors responsible for ADP-induced release reaction of human platelets. Amer. J. Physiol., 228 ; 1757, 1975.

9) Holmsen, H.: Are platelet shape change, aggregation, and release reaction tangible manifestations of one basic platelet function? in Platelets: Production, Function, Transfusion, and Storage. ed. by Baldini, M.G. \& Ebbe, S., Grune \& Stratton, New York, pp. 207, 1973.

10) Salzman, E.W. and Levine, L.: Cyclic 3', $5^{\prime}$-adenosine monophosphate in human blood platelets. II. Effect of $\mathrm{N}^{6}-2^{\prime}$-O-dibutyryl cyclic $3^{\prime}, 5^{\prime}$-adenosine monophosphate on platelet function. J. Clin. Invest., 50 ; 131, 1971.

11) Kitahara, T., Fujimaki, M. and Fukutake, K.: Studies on platelet release reaction and its inhibition. The 16th International Congress of Hematology, Kyoto, Sept., 1976.

12) Booyse, F.M., Marr, J., Yang, D-C., Guilliani, D. and Rafelson, Jr. M.E.: Mechanism of cyclic adenosine $3^{\prime}, 5^{\prime}$-monophosphate regulation of platelet membrane phosphorylation-dephosphorylation, $\mathrm{Ca}$ binding and aggregation., in platelets. ed. by Ultin, O.N., pp. 84, Excepta Medica, Amsterdam/American Elsevier, New York, 1975.

13) Halsam, R. J. and McClenagham, M. D.: Effects of collagen and of aspirin on the concentration of guanosine $3^{\prime}, 5^{\prime}$-cyclic monophosphate in human blood platelets; Measurement by a prelabelling technique. Biochem. J., 138 ; 317, 1974.

14) Hidaka, H. and Asano, T.: Human blood platelet $3^{\prime}, 5^{\prime}$-cyclic nucleotide phosphodiesterase. Isolation of low-Km and highKm phosphodiesterase. Biochim. Biophys. Acta, 429; 485, 1976. 
15) Smith, J.B. and Willis, A.L.: Furmation and release of prostaglandins by platelets in response to thrombin. Brit. J. Pharmacol., $40 ; 545,1970$.

16) Weiss, H.J.: Platelet physiology and abnormalities of platelet functions (first of two parts). New Engl. J. Med., $293 ; 531$, 1975.

17) Willis, A.L. and Kuhn, D.C.: A new potential mediator of arterial thrombosis whose biosynthesis is inhibited by aspirin. Prostaglandins, $4 ; 127,1973$.

18) Hamberg, M., Svensson, J., Wakabayashi, T. and Samuelsson, B.: Isolation and structure of two prostaglandin endoperoxides that cause platelet aggregation. Proc. Natl. Acad. Sci. USA, 71 ; 345, 1974.

19) Malmsten, C., Hamberg, M., Svensson, J. and Samuelsson, B.: Physiological role of an endoperoxide in human platelets: hemostatic defect due to platelet cyclo-oxygenase deficiency. Proc. Natl. Acad. Sci. USA, $72 ; 1446,1975$.

20) Hamberg, M., Svensson, J. and Samuelsson, B.: Prostaglandin endoperoxides. A new concept concerning the mode of action and release of prostaglandins. Proc. Natl. Acad. Sci. USA, 72 ; 2994, 1975.

21) Booyse, F. M. and Rafelson, M. E. Jr.: Studies on human platelets. III. A contractile protein model for platelet aggregation. Blood, 33; 100, 1969.

22) Baenziger, N.L., Brodie, G.N. and Majerus, P.W.: A thrombin-sensitive protein of human platelet membranes. Proc. Nat. Acad. Sci., 68 ; 240, 1970.

23) Levy-Tólédano, S.: Receptor for adrenaline on thrombostenin. in Platelet Aggregation. ed. by Caen, J., pp. 155, Masson et Cie, Paris, France, 1971.

24) Nachaman, R. L. and Ferris, B.: Binding of adenosine diphosphate by isolated membranes from human platelets. J. Biol. Chem., 249 ; 704, 1974.

25) Nilsson, I. M. and Öckerman, P.A.: The bleeding disorder in hepatomegalic forms of glycogen storage disease. Acta Paediat. Scand., 59 ; 127, 1970.

26) O'Neill, B.J. and Hutton, R.A.: Prolonged bleeding time in congenital heart disease, the association of clinical pathologists ; 75th general meeting. J. Clin. Path., $19 ; 99,1966$.

27) McClure, P. D., Ingram, G. I., Stacey, R. S., et al.: Platelet function tests in thrombocythaemia and thrombocytosis. Brit. J. Haemat., $12 ; 478,1966$.

28) Pitney, W. R., Hinterberger, H. and Potter, M.: Adenine nucleotides in platelets from normal and uraemic subjects. The effect of passage through glass bead filters. Thrombos. Diathes. Haemorrh., 19; 36, 1968.

29）遠藤安行：血小板粘着能に関する研究. 測定 条件の基礎的吟味と疾患別変動並びに影響因 子に関する検討. 日血会誌，37；796, 1974.

30) Salzman, E. W.: Blood platelets and extracorporeal circulation. Transfusion, 3;274, 1963.

31) Bennett, P.N., Dhall, D.P., McKenzie, F. $\mathrm{N}$, et al.: Effects of dextran infusion on the adhesiveness of human blood-platelets. Lancet, 2 ; 1001 , 1966.

32) Clancy, R., Jenkins, E. and Firkin, B.: Qualitative platelet abnormalities in idiopathic thrombocytopenic purpura. New Engl. J. Med., 286; 622, 1972.

33) Inceman, S. and Tangün, Y.: Platelet defects in the myeloproliferative disorders. Ann. N.Y. Acad. Sci., 201 ; 251, 1972.

34) Inceman, S. and Tangün, Y.: Impaired platelet-connective tissue reaction. New Engl. J. Med., 281 ; 108, 1969.

25) Endresen, G. K. M. and Gruner, O. P. N.: Platelet surface interaction (Stickiness) following aspirin administration in rats. II Congress Int. Soc. Thrombosis and Haemostasis, Oslo, 1971, Abstract 196.

36) Mayne, E. E., Bridges, J. M. and Weaver, J.A.: Platelet adhesiveness, plasma fibrinogen and factor VIII levels in diabetes mellitus. Diabetologia, 6;436, 1970. 
37) Horlick, L.: Platelet adhesiveness in normal persons and subjects with atherosclerosis. Effect of high fat meals and anticoagulants on the adhesive index. Amer. J. Cardiol., 8; 459, 1961.

38) Nestel, P.J.: A note on platelet adhesiveness in ischaemic heart disease. J. Clin. Path., 14 ; 150, 1961.

39) Enticknop, J.B., Gooding, P.G., Lansley, T.S., et al.: Platelet size and function in ischemic heart disease. J. Atheroscler. Res., 10; 41, 1969.

40) Parreira, F. and Ducla-Soases, A.: Ätiologische Aspekt der Thrombozytopathie. Münch. Med. Wschr., 111 ; 2640, 1969.

41) Rabiner, S. F.: Bleeding in uremia, Symposium on Hemorrhagic Disorders. ed. by Rossi, E.C., Med. Clin. North. Amer., 56 ; 221, 1972.

42) Zucker, M.B. and Peterson, J.: Inhibition of adenosine diphosphate-induced secondary aggregation and other platelet function by acetylsalicilic acid ingestion. Proc. Soc. Exp. Biol. Med., 127 ; 547, 1968.

43) Cotton, C.: The effect of pyridinol carbamate on the platelet response to ADP in patients with intermittent claudication. in Tokyo Conference on Atherogenesis, Thrombogenesis and Pyridino-carbamate Treatment. Tokyo, 18, 1972.

44) Salzman, E.W. and Neri, L.L.: Adhesiveness of blood platelets in uremia. Thrombos. Diathes. Haemorrh., 15; 84, 1966.

45) O'Brien, J.R., Herwood, J. B. and Heady, J.A.: The quantitation of platetet aggregation induced by four compounds: A study in relation to myocardial infarction. Thrombos. Diathes. Haemorrh., 16; 752, 1966.

46) Yamazaki, H.: Platelet functions in thro- mboembolic disorders. in Platelets. ed. by Ultin, O. N., pp. 275, Excepta Medica, Amsterdam/American Elsevier, New York, 1975.

47) Holmsen, H., Day, H. J. and Stormorken, H.: The blood platelet release reaction. Scand. J. Haemat., suppl., 8; 3, 1969.

48) Caen, J. P., Castaldi, P. A., Leelerc, J. C., Inceman, S., Larrieu, M. J., Probst, M. and Bernard, J.: Congenital bleeding disoders with long bleeding time and normal platelet count. 1. Glanzman's thrombasthenia (report of fifteen patients). Amer. J. Med., 41 ; 4, 1966.

49) Kowalski, E., Kopeć, M., Wçgrynowicz, Z., Hurwic, M. and Budzyński, A.Z.: A lysosomal concept of the platelet release reaction and viscous metamorphosis. Thrombos. Diathes. Haemorrh., 16; 134, 1966.

50）北原 武：血小板放出反応とその阻止につい て. 東医大誌, $34 ; 717,1976$.

51) Bowie, E.J.W. and Owen, C. A.: Thrombopathy. Seminars in Hematol., 5; 73, 1968.

52) Kanfer, A. and Josso, F.: Hyperactivité plaquettaire au cours de la coagulation intravasculaire. Etude experimentale chez le lapin. Rev. Europ. Etud. Clin. Biol., $16 ; 814,1971$.

53）細川 孝, 他：血小板容積の正常值と保存に よる変化. 臨床病理, 22 (補冊); 92, 1974.

54) 山田兼雄 : Bernard-Soulier syndrome (macrothrombocytic thrombopathia) の血小板機 能に関する検討. 臨床血液， 15；915，1974.

55) Gröttum, K. A., Hovig, T., Holmsen, H., Abrahamsen, A.F., Jeremic, M. and Seip, M.: Wiskott-Aldrich syndrome: Qualitative platelet defects and short platelet survival. Brit. J. Haemat., 17 ; 373, 1969. 